\title{
Production of Polyunsaturated Fatty Acids (PUFAs) from Microbes and their Secondary Metabolites
}

\author{
K.C. Naveena* and Ramalingappa
}

Department of Microbiology, Davangere University, Davangere-577007, Karnataka, India

*Corresponding author

\section{A B S T R A C T}

\begin{tabular}{|c|}
\hline Keywords \\
\hline $\begin{array}{l}\text { Polyunsaturated } \\
\text { fatty acids, } \\
\text { Secondary } \\
\text { metabolites, } \\
\text { Thraustochytrids }\end{array}$ \\
\hline Article Info \\
\hline $\begin{array}{l}\text { Accepted: } \\
20 \text { November } 2018 \\
\text { Available Online: } \\
10 \text { December } 2018\end{array}$ \\
\hline
\end{tabular}

\section{Introduction}

Microbial lipids, particularly the single cell oils are generally acknowledged in the commercial center with the expansion in familiarity with the wellbeing benefits of PUFAs. The customer's interest for SCO oil is expanding and anticipated to grow constantly. The major nutraceuticals of these lipids classes are docosahexaenoic acid (DHA), eicosapentaenoic acid (EPA), Gamma linolenic acid (GLA) and arachidonic acid (ARA). Plants are not skilled to blend these long chain exceptionally unsaturated fats with the exception of GLA which is expectedly delivered from the seeds of night primorse, borage and blackcurrant. As another option to plant and animal based oils, look into is being centered around screening and disengagement of new oleaginous microorganisms, which has investigated certain growths, microscopic organisms, green growth and yeasts blending microbial oils having long chain unsaturated fats (Syed et al., 2006).

In generally polyunsaturated fatty acids (PUFAs) are constituents of the cell membrane and the primary structural components of the brain, skin, sperm, testicles, and retina (Liao et al., 2016). PUFAs start from plants are expended in higher wealth than those from angle, with the goal that plant 
omega-6 PUFA are devoured in higher amounts than omega-3 PUFA (Newton 1998). This over utilization of omega-6 with respect to omega-3oil has been connected to expanded danger of tumor, diabetes, cardiovascular and neurodegenerative ailment (Simopoulos, 2006). To reestablish an adjust, utilization of omega-3 unsaturated fats ought to be expanded contrasted with omega-6 unsaturated fats. Omega 6 to omega-3 PUFA proportions of between 5:1 and 3:1 have been proposed as ideal for human utilization (Simopoulos, 2008).

The advancement of microbial lipid generation has essentially been focused on the living being determination and improvement of social conditions. Shockingly, less consideration has been centered on oil confinement, while most extraction strategies connected to microbial framework have been initially portrayed for creature tissues and plant materials. Accordingly, dependable procedures for recuperation and decontamination of microbial oils must be utilized to additionally build up this region of microbial biotechnology (Suzuki and Yokochi, 1989; Certik, 1996; Davies, 1988). A few investigations have tended to the remedial impacts of omega-3 PUFAs in tumor demonstrating that omega-3 PUFAs can enhance viability and fairness of chemotherapy (Bougnoux et al., 2009; Nabavi et al., 2015). DHA as a treatment methodology is regularly joined with chemotherapeutic medications since DHA in all probability upgrades the cytotoxic impacts of these medications (Nabavi et al., 2015).

In the ongoing years, the structure of the cell film unsaturated fats has been explored, not just as a factor affecting the reaction to medications, yet additionally as a component impacting BC guess free of the treatment got (Bougnoux et al., 2009, 2010; Straka et al., 2015). Connecting BRCA to key dietary variables, for example, omega-3 PUFAs, associated with the rate of BC (Brasky et al., 2010; Molfino et al., 2016), opens wide points of view for healthful avoidance in $\mathrm{BC}$ and in conceivably tweaking fiery status. As of late, Roy et al., recorded positive relationship amongst erythrocyte and bosom tissue omega3 unsaturated fats, and suggestive reverse relationship between erythrocyte long chain omega-3 PUFAs and tissue Creative protein (CRP) (Roy et al., 2015). This review includes types fatty acids produced microorganisms, optimisation of PUFAs and secondary metabolites of Thrastochytrids.

\section{Some plyunsturated fatty acids obtoained by microorganisms}

Many types of PUFAs have been obtained from different microorganisms including microalgae, bacteria, fungi and yeasts that produce omega-3 and omega- 6 polyunsaturated fatty acids. Examples are arachidonic acid (ARA), gamma linolenic acid, ducosahexaenoic acid, eicosapentaenoic acid and linolenic acid (Gupta et al., 2011) (Table 1).

\section{Other polyunsaturated fatty acids}

For human health, plants were initially considered as the main source of PUFAs, especially gamma linolenic acid (GLA) which was accessible and economically high. The primary disadvantage of using PUFAs produced by plants is that many qualities are built to produce polyunsaturated fat for business purpose; without this innovation, there is low probability of DHA creation utilizing designed oil seed products (Alonso and Maroto, 2000).

Microbial long chain omega- 6 polyunsaturated fatty acids for ex. Gamma linolenic acid (18:3), dihomo-gamma-linelonic acid (20:3) and arachidonic acid (20:4) have been 
reported (Ratledge, 2001). The main business oil obtained from organisms that was gamma linolenic acid (GLA), predominantly GLA was extracted by growths of lower phycomycetes, and other sources such as Pythium debaryanm containing small amount of lipids (Shaw, 1965). Schizochytrium and Cryptoconidium sp., the source of DHA and Mortierella sp., are the major sources of ARA. These organisms are free from toxicity and pathogens; both DHA and ARA are used for infants (Ward, 2005).

\section{Microbial polyunsaturated fatty acid (PUFAs) production}

To increase the product value of microbial lipids as compared to animal and plant derived oils, a variety of things have been done such as introduction of inexpensive agro-industrial substrates. Screening the potential oil producing organisms is the important step, which reduces the numerous strains of microbes for further study and they are essential for practical study. These strains can directly be used for optimization study. Production of maximum PUFAs depends on the availability of various nutrients and their compositions (Kennedy et al., 1993). There are two basic processes involved in microbial lipid production, such as submerged and solid state fermentation.

\section{Submerged fermentation}

Submerged fermentation needs frequent nutrients and oxygen for the growth of aerobes. The cells growth and product formation of the microorganisms are influenced strongly by media components. In this process microbes are cultivated in a liquid medium under controlled conditions for the production of products. Submerged fermentation is used for microbial lipid production; particularly in single cell oil industries. The development of microbes requires a procedure that comprises a few operation units, from microbial development in bioreactors to oil processing (Syed et al., 2006) (Table 2). There are three essential operations which require extraordinary regard for the procedure advancement, inferable from the idea of oleaginous life forms: (1) Optimized conditions in fermentation; (2) Cell separation as intracellular oil; (3) Disruption of cells, extraction of oil and processing (refining).

Since the financial considerations of microbial PUFAs generations of microbial are seriously influenced by the cost of crude material feedstock, for the most part nitrogen constrained choice of development media is a vital stride. It ought to be noticed that obtaining satisfaction from the media for the screening procedure is unique in relation to expansive scale creation media under ideal fermented conditions (Certik, 1999).

\section{Solid state fermentation}

In the solid state fermentation, microbes are cultivated on a substrate of moist solid free from water; it allows the utilization of food and agro-industries' raw material and some other cheap raw materials as substrates (Pandey, 1992). Strong state aging is a minimal effort put in aging procedure; it is appropriate for agro mechanical buildups of the substrates in bio-processes. Solid state fermentation is known in the ancient Asian nations, yet it is almost disregarded in present day world (Pandey et al., 2001).

Solid state fermentation forms are appropriate for the generation of hydrolytic chemical by filamentous growth, since they imitate normally the regular living states of parasites (Singhania et al., 2009). Consideration towards this bioprocess is a result of many focal points in contrast to submerged maturation e.g. Littler bioreactor volume, 
diminished downstream preparing cost, high efficiency, easier strategy, lessened vitality requirement, low waste water yield, etc. (Kim et al., 1985; Burke and Cairney, 1997). In solid state fermentation (SSF), substrates are used as solid for cultivation, since the success of the procedure relies upon it to a great extent. The two most essential parts in solid state fermentation process are: Exchange of oxygen to the developing microorganisms and exchange of supplements and proteins inside the substrate strong mass; it also involves keeping of the coveted temperature by expelling the warmth created during aging. Generally, development of SSF involves following necessary steps. (1) Screening of isolated microorganisms; (2) Optimization studies through different parameters; (3) Establishment and designing of the pilot plant when scale up is necessary; (4) Data generation and commercial plant design; (5) Plant construction; (6) Regular plant operation for microbial metabolites production (Certik et al., 1999).

A case of SSF is use of Microsphaeropsis sp., to deliver SCO from a substrate comprising of steam detonated wheat straw and wheat grain; there are likewise few reports on creation of GLA under SSF. The scale up region is under investigation and broad research is required on the path for microbial oils creation. This could quicken creation of advertisement for PUFA generation (Syed et al., 2006) (Table 3).

Enriched glycerides, unsaturated fats and esters for biometrically and nutraceutical uses can be acquired by lipase catalyzed hydrolysis, alcoholysis, acidolysis, glycerolysis, and transesterification of fish, microbial oils and plant seed (Gill and Valvety, 1997) (Table 4).

\section{Secondary metabolites of Thrastochytrids}

Thraustochytrids are able to create auxiliary metabolites e.g, steroids, sterols, carotenoids and surfactants (Fan and Chen, 2007; Lewis et al., 2001). Besides, they are additionally a wellspring of extracellular polysaccharides and biocatalysts.

\section{Enzymes}

Thraustochytrids secrete a number of enzymes and compounds, for example, protease, esterase, lipase, corrosive and basic phosphate, cellulases and xylanases (Raghukumar, 2008). The additional cell lypolytic action was concentrated on 19 strains of Thrautochytrids, with 14 of them utilizing carboxymethyl cellulose (CMC) as substrate. The hydrolysis of the substrate CMC affirms the presence and action of cellulase in Thraustochytrids (Nagano et al., 2011).

\section{Carotenoids}

Thraustochytrids are promising well spring of carotenoids including PUFAs.

The generation of carotenoid colors, for example, astaxanthin, zeaxanthin, canthaxanthin, echinenone, phoenicoxanthin and $\beta$-carotene by Thraustochytrium sp. has been accounted (Burja et al., 2006 and Carmona et al., 2003). As $\beta$-carotene is a forerunner of vitamin $A$, adequate admission of $\beta$-carotene can prevent malady created by vitamin A inadequacy, including visual deficiency, safe brokenness and skin issue (Fierce et al., 2008).

\section{Extracellular polysaccharides}

Thraustochytrids are reported to produce extracellular polysaccharide (EPS) that incorporate sugars as the real part (39-53\%) with the vicinity of proteins, lipids, uronic acids and sulfates (Jain et al., 2005). EPS is an antitumor and antiviral agent and can likewise be utilized as a part of the corrective and nourishment commercial ventures (Sutherland, 1998). 
Table.1 Polyunsaturated fatty acids (\% of total fatty acids) obtained from microorganisms

\begin{tabular}{|c|c|c|c|}
\hline Fatty acid & TFA $(\%)$ & Microorganism & References \\
\hline $\mathbf{A A}$ & 25.9-53.8 & Mortierella sp. & Suzuki et al., (2010) \\
\hline ALA & 33-41 & Mortierella alliacea & Jermstuntiea et al., (2011) \\
\hline ALA & 4.1-5.4 & Rhodotorula muciloginosa & Gupta et al., (2011) \\
\hline ARA & 11 & Mortierella alpinapeyron & Kendrick and Ratledge (1992) \\
\hline ARA & 68.5-78.8 & Mortierella alpine & Totani and Oba (1987) \\
\hline DGLA & 4.7-4.9 & Mortierella sp. & Suzuki et al., (2010) \\
\hline DHA & $0.7-0.8$ & Colwellia sp. & Bowman et al., $(1997,1998)$ \\
\hline DHA & 32 & Pichia methanolica & Aoki et al., (2002) \\
\hline EPA & 1.3-13 & Mortierella alliacea & Jermstuntiea et al., (2011) \\
\hline EPA/ARA & $18 / 19$ & Saprolegnia parasitica & Kendrick and Ratledge (1992) \\
\hline EPA and DHA & 2.8 and 6.7 & Candida guilliermondii & Guo and Ota (2000) \\
\hline EPA & $2-22$ & Shwenella sp. & Nichols and McMeekin (2002) \\
\hline EPA & 25.2 & Pythium irregular & O'Brien et al., (1993) \\
\hline GLA & 10.4 & Pythium debaryanam & Shaw (1965) \\
\hline GLA & 4.3-4.7 & Mortierella sp. & Suzuki et al., (2010) \\
\hline Linoleic acid & 24.7 & Rhodotorula muciloginosa & Gupta et al., (2011) \\
\hline Oleic acid & & 45.4 & muciloginosa \\
\hline Gupt: & (2011) & & \\
\hline
\end{tabular}

Table.2 Polyunsaturated fatty acids produced from microbes through sub-merged fermentation

\begin{tabular}{|c|c|c|c|c|c|}
\hline $\begin{array}{l}\text { Microorganisms } \\
\text { Involved }\end{array}$ & Parameter & $\begin{array}{l}\text { of } \\
\text { are }(\mathrm{h})\end{array}$ & Analysis of PUFA & PUFA (\%) & Reference \\
\hline Thraustochytrids & $\begin{array}{l}\text { Screening for production } \\
\text { of DHA }\end{array}$ & 107 & $\begin{array}{l}\text { DHA creation fortified at high C:N greater than } \\
1 \% \text { glucose hinders } T \text {. aurem development. Lipid } \\
\text { amassing was } 25 \% \text { and productivity rate was } 0.48 \mathrm{~g} / \mathrm{l} / \mathrm{day}\end{array}$ & $2.17(\mathrm{~g} / \mathrm{l})$ & Bowels et al., (1999) \\
\hline M. alpine & $\begin{array}{l}\text { Production of ARA on } \\
\text { temperature and composition } \\
\text { of media }\end{array}$ & 192 & $\begin{array}{l}\text { The production of } \mathrm{ARA} \text { was } 1.14 \mathrm{~g} / \mathrm{l} / \mathrm{day} \text {, when } \\
\text { vegetable oil, } \mathrm{NaNO}_{3} \text { and soy flour were used as } \\
\text { a medium in glucose fed batch cultures }\end{array}$ & $9.1(\mathrm{~g} / \mathrm{l})$ & Singh and Ward (1997) \\
\hline $\begin{array}{l}\text { Mortierella } \\
\text { ramanniana }\end{array}$ & Submerged fermentation & 102 & $\begin{array}{l}\text { M. ramanniana has to be excellent producer of } \\
\text { gamma linolenic acid, when temperature was at } \\
20 \text { to } 21^{\circ} \text { and media contain dextrose }(5 \%) \text {, yeast } \\
\text { extract }(1 \%) \text { and } \mathrm{Mn}^{2+}(5 \mathrm{mg} / \mathrm{ml})\end{array}$ & $13.3(\mathrm{~g} / \mathrm{l})$ & Dyal and Nairine (2005) \\
\hline $\begin{array}{l}\text { Cunninghamella } \\
\text { echinulata }\end{array}$ & $\begin{array}{l}\text { Parasite developed on } \\
\text { tomato squander hydrolysate }\end{array}$ & 300 & $\begin{array}{l}\text { C. echinulata found to produce of GLA more } \\
\text { than } 1 \mathrm{~g} / \mathrm{l} \text { in favour of glucose }\end{array}$ & $11.7(\mathrm{~g} / \mathrm{l})$ & Fakas et al., (2008) \\
\hline
\end{tabular}


Table.3 Production of gamma linolenic acid under solid state fermentation

\begin{tabular}{|c|c|c|c|c|}
\hline Substrate used & $\begin{array}{l}\text { Investigated } \\
\text { mould }\end{array}$ & $\begin{array}{c}\text { Fermented biomass } \\
\text { Oil }(\mathrm{W} / \mathrm{w} \%)\end{array}$ & $\begin{array}{l}\text { Gamma linolinic acid } \\
(\%) \text { in TFA }(W / \mathrm{w} \%)\end{array}$ & Reference \\
\hline Soaked barley & Cunninghamella japonica & 14.3 & 29.1 & Emelyanova (1996) \\
\hline $\begin{array}{l}\text { Orange peel }+ \text { spent } \\
\text { malt grain }\end{array}$ & Mortierella isabelina & 16.8 & 4.23 & Stredansky et al., (2000) \\
\hline Pearl barly & Thamnidium elegans & 15.6 & 9.3 & Conti et al., (2001) \\
\hline Orange peel + glucose & Cunning hamella & - & 5.1 & Gema et al., (2002) \\
\hline
\end{tabular}

Table.4 PUFAs in plants and animals lipid catalysed by lipase

\begin{tabular}{|c|c|c|c|c|c|}
\hline Sources of lipid & PUFAs & Lipase catalyst & Reaction & PUFA product & Reference \\
\hline $\begin{array}{l}\text { Sand eel (oil) } \\
\text { (1997) }\end{array}$ & DHA & Rhizomucor miehei & Esterification & Free fatty acids & Langholz et al., (1989); Gill and Valvety \\
\hline $\begin{array}{l}\text { Cod liver (oil+ FFAs) } \\
\text { (1997) }\end{array}$ & EPA/DHA & Rhizomucor miehei & Acidolysis & Gs (Triglycerides) & Yamane et al., (1992); Gill and Valvety \\
\hline $\begin{array}{l}\text { Cod liver (oil+ FFAs) } \\
\text { (1997) }\end{array}$ & EPA/DHA & Rhizomucor miehei & Acidolysis & Gs (Triglycerides) & Yamane et al., (1993); Gill and Valvety \\
\hline Cod liver (oil) & EPA+DHA & Pseudomonas sp. & Alcoholysis & Mono+Diglycerides+FFAs & Li and Ward (1993); Gill and Valvety (1997) \\
\hline $\begin{array}{l}\text { Tuna (oil) } \\
\text { (1997) }\end{array}$ & DHA & Candida cylindracea & Hydrolysis & Glycerides (di+triglycerides) & Tanaka et al., (1993); Gill and Valvety \\
\hline $\begin{array}{l}\text { Tuna (oil) } \\
\text { (1997) }\end{array}$ & EPA+ DHA & Geotrichum candidum & Hydrolysis & Glycerides (triglycerides) & Shimada et al., (1994); Gill and Valvety \\
\hline $\begin{array}{l}\text { Menhaden (oil) } \\
\text { (1997) }\end{array}$ & EPA & Pseudomonas sp. & Hydrolysis & Glycerides (mono glycerides) & Maehr et al., (1994); Gill and Valvety \\
\hline $\begin{array}{l}\text { Sardine (oil+ FFAs) } \\
\text { (1997) }\end{array}$ & EPA/DHA & Rhizomucor miehei & Acidolysis & Glycerides (triglycerides) & Hosokawa et al., (1995); Gill and Valvety \\
\hline
\end{tabular}

DHA, Docosahexaenoic acid, EPA, Eicosapentaenoic acid, FFAs, Free fatty acids.

EPS are found to assume a critical part in the cell life of Thraustochytrids. They may shield Thraustochytrids from drying up; help with the phone adherence to the marine substrate and serve as a source of vitality during starvation (Jain et al., 2005). Thraustochytrids might likewise manage the cost of security against metal and poison sullying (Colaco et al., 2006).

In conclusion, the pivotal role of biochemical parts of polyunsaturated fats has concentrated on PUFA amoreliate nutraceuticals and therapeutics and in light of the arrangement of reasonable engineered systems for their creation. The diverse constituents of media assumed a vital part for creation of wanted lipid in any maturation procedure. It is inferred that supplement constraint, generally nitrogen, is the key figure inciting lipid aggregation oleaginous microorganisms. At show, the deficiency of expansive scale innovations for giving modest, decontaminated PUFAs has enormously confined endeavors toward this path. Be that as it may, modern interests in PUFA biomedical ought to quicken the improvement of biotechnological courses to high review 
omega-3 and omega-6 PUFAs. Significant endeavors officially under approach to market lipase-interceded process, and this should, with the advancement of microbial and plant based generation frameworks, before long make vast amounts of PUFAs accessible for manufactured employments. Thrastochytrids can be utilizing full wellspring of omega-3 unsaturated fats, carotenoids, proteins and other important mixes.

\section{Conflict of Interests}

The authors declare that they have no conflicts of interest for publication.

\section{References}

Alonso, DL. Maroto, FG. 2000. Plants as chemical factories for the production of polyunsaturated fatty acids. Journal of Biotechnology Advances, 18(6): 481497.

AokI, H. Miyamoto, N. Furuya, Y. Mankura, M. Endo, Y. Fujimoto, K. 2002. Incorporation and accumulation of docosahexaenoic acid from the medium by Pichia methanolica HA-32. Journal of Bioscience, Biotechnology and Biochemistry. 66(12): 2632-2638.

Bougnoux, P. Hajjaji Maheo, K. Couet, C. 2010. Chevalier S. Fatty acids and breast cancer: sensitization to treatments and prevention of metastatic re-growth. Journal of Progress in Lipid Research, 49:76-86.

Bougnoux, P. Hajjaji, N. Ferrasson, MN. Giraudeau, B. Couet, C. Le Floch, O. 2009. Improving outcome of chemotherapy of metastatic breast cancer by docosahexaenoic acid: a phase II trial. Brazilian Journal of Cancer, 101: 19781985.

Bowles, RD. Hunt, AE. Bremer, GB. Duchars, MG. Eaton, RA. 1999. Long-chain n-3 polyunsaturated fatty acid production by members of the marine protistan group the Thraustochytrids: screening the isolates and optimisation of DHA production. Journal of Biotechnology, 70(1): 193-202.

Bowman, JP. Gosink, JJ. Mccammon, SA. Lewis, TE. Nichols, DS. Nichols, PD. 1998. Colwelliademingiae sp. nov, Colwelliahornerae sp. nov, Colwelliarossensis sp. nov. and Colwellia psychrotropica sp. nov. Psychrophilic antarctic species with the ability to synthesize docosahexaenoic acid (22:6, $\omega-3)$. International Journal of Systematic Bacteriology, 48: 1171-1180.

Bowman, JP. McCammon, SA. Nichols, DS. Skerratt, JH. Rea, SM. Nichols, PD. 1997. Shewanella gelidimarina sp. nov. and Shewanella frigidimarina sp. nov, novel Antarctic species with the ability to produce eicosapentaenoic acid (20:5, $\omega-3)$ and grow anaerobic ally by dissimilatory $\mathrm{Fe}$ (III) reduction. International Journal of Systematic Bacteriology, 47(4): 1040-1047.

Brasky, TM. Lampe, JW. Potter, JD. Patterson, ER. White, E. 2010. Specialty supplements and breast cancer risk in the vitamins and life style (VITAL) cohort. Cancer epidemiology. Journal of Biomarkers and Prevention, 19(7):16961708.

Burja AM. Radianingtyas, H. Barrow, CJ. 2006. Isolation and characterization of polyunsaturated fatty acid producing Thraustochytrium species: screening of strains and optimization of omeha-3 production. Journal of Applied microbiology and Biotechnology, 72:1161-1169.

Burke, RM. Cairney, JWG. 1997. Carbohydrolyse production by the ericoid mycorrhizal fungus Hymenoscyphus ericae under solid state fermentation conditions. Journal of Mycological Research, 10: 1135-1139.

Carmona, ML. Naganuma, T. Yamaoka Y. 2003. Identification by HPLC-MS of carotenoids of the Thraustochytrium CHN-1 strain isolated from the seto inland sea. Journal of Bioscience 
Biotechnology and Biochemistry, 67:884888.

Certik, M. Andrasi, P. Sajhidor, J. 1996. Effect of extraction methods on lipid yield and fatty acid composition of lipid classes containing $\Upsilon$-linolenic acid extracted from fungi. Journal of American Oil Chemists Society, 73: 357-365.

Certik, M. Shimizu, S. 1999. Biosynthesis and regulation of microbial polyunsaturated fatty acids production. Journal of Bioscience and Bioengineering, 87:1-14.

Colaco, A. Raghukumar, C. Mohandass, C. Santos, RS. 2006. Effect of shallow water venting in Azores on a few marine biota. Journal of Cahiers De biology Marine, 47(4): 359-364.

Conti, E. Stredansky, M. Stredansky, S. Zanetti, F. 2001. Y-Linolenic acid production by solid state fermentation of Mucorales strains on cereals. Journal of Biosource Technology, 76: 283-286.

Davies, RJ. 1988. Yeast oil from cheese wheyprocess development, in single cell oil, Moreton Rs (ed). Longman Scientific and Technical. New York, 99-145.

Dyal, SD. Nairine, SS. 2005. Implications for the use of Mortierella fungi in the industrial production of essential fatty acids. International journal of Food Research, 38(4): 445- 467.

Emelyanova, EV. 1996. Y-Linolenic acid production by Cunninghamella japonica in solid state fermentation. Journal of Process Biochemistry, 31:431-434.

Fakas, S. Papanikolaou, S. Galiotou-Panayotou, M. Komaitis, M. Aggelis, G. 2008. Organic nitrogen of tomato waste hydrolysate enhances glucose uptake and lipid accumulation in Cunninghamella echinulata. Journal of Applied Microbiology, 105: 1062-1070.

Fan, KW. Chen, F. Production of high value products by marine micro algae thraustochytrids. Bioprocessing for value added products from renewable resources. Amsterdam: Elsevier: 2007. P. 293-324. Sutherland, IW. 1998. Novel and established applications of microbial polysaccharides. Trends in Biotechnology, 16:41-46.

Fierce, Y. De Mories Vieira, M. piantedosi, R. Wyss, A. Blaner, WS. Paik, J. 2008. Invitro and invivo characterization of retinoid synthesis from $\beta$-carotene. Arch. Journal of Biochemistry and Biophysics, 472:126-138.

Gema, H. Kavadia, A. Dimou, D. Tsagou, V. Komaitis, M. Aggelis, G. 2002. Production of $\Upsilon$-Linolenic acid by Cunninghamella echinulata cultivated on glucose and orange peel. Journal of Applied Microbiology and Biotechnology, 58(3):303-307.

Guo, X. Ota, Y. 2000. Incorporation of eicosapentaenoic acid and docosahexaenoic acids by yeast. Journal of Applied Microbiology, 89:107-115.

Gupta, A. Barrow, CJ. Puri, M. 2011. Screening and molecular identification of marine organisms for advancing omega 3 biotechnology. 4th International Conference in Environment Science and Engineering (CESE), Tainan City, Taiwan, 25-30 September.

Hosokawa, M. Takahashi, K. Miyazaki, N. Okamura, K. Hatano, M. 1995. Journal of the American Oil Chemists Society, 72(4): 421-425.

Iqbal, G. Valivety, R. 1997. Polyunsaturated fatty acids, Part I: Occurrence, biological activities and applications. Journals of Trends in Biotechnology, 15(10): 401409.

Jain, R. Raghukumar, S. Tharanath, R. Bhosle, NB. 2005. Extracellular polysaccharide production by thraustochytrid protists. Journal of Marine Biotechnology, 7:184192.

Jermsuntiea, W. Aki, T. Kawamoto, S. Ono, K. 2011. Metabolism and synthesis of lipids in the polyunsaturated fatty acidproducing fungus Mortierella alliacea. Journal of Oleo Science, 60(1): 11-17.

Kendrick, A. Ratledge, C. 1992. Lipids of selected molds grown for production of $\mathrm{n}-3$ and $\mathrm{n}-6$ polyunsaturated fatty acids. Journal of Lipids, 27(1): 15-20. 
Kennedy, MJ. Reader, SL. Davies, RJ. 1993. Fatty acid production characteristics of fungi with particular emphasis on gamma linolenic acid production. Journal of Biotechnology and Bioengineering, 42: 625-634.

Kim, JH. Hosobuchi, M. Kishmoto, M. Seki, T. Yoshida, T. Taguchi, H. Ryu, DDY. 1985. Cellulase production by solid state culture system. Journal of Biotechnology and Bioengineering, 27:1445-1450.

Langholz, P. Anderson, P. Forskov, T. Schmidtsdorff, W. 1989. Journal of American Oil Chemist Society, 66:11201123.

Lewis, TE. Nichols, PD. Mc Meekin, PA. 2001. Sterol and squalene content of a docosahexaenoic acid producing thraustochytrid: influence of culture age, temperature and dissolved oxygen. Journal of Marine Biotechnology, 3: 439447.

Li, ZY. Ward, OP. 1993. Production of DHA by Thraustochytrium roseum. Journal of Biotechnology Letters, 15: 393-398.

Li, ZY. Ward, OP. 1994. Production of DHA by Thraustochytrium roseum. Indian journal of Microbiology and Biotechnology, 13:238-241

Maehr, H. Zenchoff, G. Coffen, DL. 1994. Enzyme enhancement of n-3 fatty acid content in fish oils. Journal of American oil chemists Society, 71(5): 463-467.

Molfino, A. Amabile, MI, Monti, M. Arcieri, S. Rossi Fanelli, F. Muscaritoli, M. 2016. The role of docosahexaenoic acid (DHA) in the control of obesity and metabolic derangements in breast cancer. International Journal of Molecular Science, 17(4):505.

Nabavi, SF. Bilotto, S. Russo, GL. Orhan, IE. Habtemariam, S. Daglia, M. 2015. Omega-3 polyunsaturated fatty acids and cancer: lessons learned from clinical trials. Cancer Metast, 34:359-380.

Nagano, N. Matsui, S. Kuramura, T. Taoka, Y. Honda, D. Hayashi, M. 2011. The distribution of extracellular cellulose activity in marine eukaryotes, thraustochytrids. Journal of Marine Biotechnology, 13: 133-136.

Newton IS. 1998. Long chain polyunsaturated fatty acid- the new frontier in nutrition. Journal of Lipid Technology, 10:77-81.

Nichols, DS. McMeekin, TA. 2002. Biomarker techniques to screen for a bacterium that produces polyunsaturated fatty acids. Journal of Microbiological Methods, 48(2-3): 161-170.

O'Brien, DJ. Kurantz, MJ. Kwoczak, R. 1993 Production of eicosapentaenoic acid by the filamentous fungus Pythium irregulare. Journal of Applied Microbiology and Biotechnology, 40(23): 211-214.

Pandey, A. 1992. Recent process developments in solid state fermentations. Journal of Process Biochemistry, 27: 109-117.

Pandey, A. Soccol, CR. Rodriguez-León, JA. Nigam, P. 2001. Production of Organic Acids by Solid-state Fermentation. In: Solid-state Fermentation in Biotechnology - Fundamentals and Applications. New Delhi: Asiatech Publishers, Inc., 113-126.

Raghukumar, S. 2011. Thraustochytrid marine protists: production of PUFAs and other emerging technologies. Journal of Marine Biotechnology, 10: 631-640.

Ratledge, C. 2001. Microorganisms as source of PUFAs. Structured and modified lipids. New York. PP. 351-399.

Ratledge, C. 2001. Microorganisms as sources of polyunsaturated, In: structured and modified lipids, Gunston FD (ed), Marcel Dekkar, Inc., New York, 351-400.

Shaw, R. 1965. The occurrence of $\gamma$-linolenic acid in fungi. Biochemistry and Biophysics Acta. 98: 230-237.

Shimada, Y. Maruyama, K. Akazaki, S. Nakamura, M. Sugihara, A. Tominga, Y. 1994. Journal of American Oil Chemists Society, 71(9): 951-954.

Simopoulos, AP. 2006. Evolutionary aspects of diet, the omega-6/omega-3 ratio and genetic variation: nutritional implications for chronic diseases. Journal of Biomed Pharma, 60:502-507. 
Simopoulos, AP. 2008. The importance of the omega-6/omega-3 fatty acid ratio in cardiovascular disease. EXP Bio Med, 233:674-688.

Singh, A. Ward, OP. 1997. Microbial production of docosahexaenoic acid (DHA, C22:6). Journal of Advanced Applied Microbiology, 45: 271-312.

Singhania, RR. Patel, AK. Soccol, CR. Pandey, A. 2009. Recent fermentation. Journal of Biochemical Engineering, 44(1):13-18.

Straka, S. Lester, JL. Cole, R.M. Andridge, RR. Puchala, S. Rose, AM. 2015. Incorporation of eicosapentaenoic and docosahexaenoic acids into breast adipose tissue of women at high risk of breast cancer: a randomized clinical trial of dietary fish and n-3 fatty acid capsules. Journal of Molecular Nutrition Food Research, 59, 1780-1790.

Stredansky, M. Conti, E. Stredanska, S. Zanetti, F. 2000. $\Upsilon$-Linolenic acid production with Thamnidium elegans by solid state fermentation on apple pomace. Journal of Biosource Technology, 73:41-45.

Suzuki, O. Ono, K. Shigeta, S. Aki, T. Akimoto, K. 2010. Process for preparing highly unsaturated fatty acid and lipid containing highly unsaturated fatty acid. European Patent, 1-12.

Suzuki, O. Yokochi, T. 1989. Increase in the $\gamma$ linolenic acid content by solvent winterization of fungal oil extracted from Mortierella genus. Journal of Japanese Oil Chemist Society, 38:1007.

Syed, AU. Guillermo, RC. Carlos, RS. Vanete, TS. Christian, L. Ashok, P. 2006. Microbial lipids. Journal of Comprehensive Food Fermentation and Biotechnology, 236-238.

Tanaka, Y. Funada, T. Hirono, J. Hashizume, R. 1993. Industrial Chemistry and Chemical Engineering. Journal of American Oil Chemist Society, 70: 1031-1034.

Totani, N. Oba, K. 1987. The filamentous fungus Mortierella alpina; high in arachidonic acid. Journal of Lipids, 22(12): 1060-1062.

Ward, OP. Singh, A. 2005. Omega-3/6 fatty acids: Alternative sources of production. Journal of Process Biochemistry, 40(12):3627-3652.

Yamane, T. Suzuki, T. Hoshino, T. 1993. Increasing n- 3 polyunsaturated fatty acid content of fish oil by temperature control of lipase- catalyzed acidolysis. Journal of American Oil Chemist Society, 70(12): 1285-1287.

Yamane, T. Suzuki, T. Shashi, Y. Vikersveen, L. Hoshino, T. 1992. Industrial Chemistry and Chemical Engineering. Journal of American Oil Chemist Society, 69: 11041107.

\section{How to cite this article:}

Naveena, K.C. and Ramalingappa. 2018. Production of Polyunsaturated Fatty Acids (PUFAs) from Microbes and their Secondary Metabolites. Int.J.Curr.Microbiol.App.Sci. 7(12): 2680-2689. doi: https://doi.org/10.20546/ijcmas.2018.712.304 